
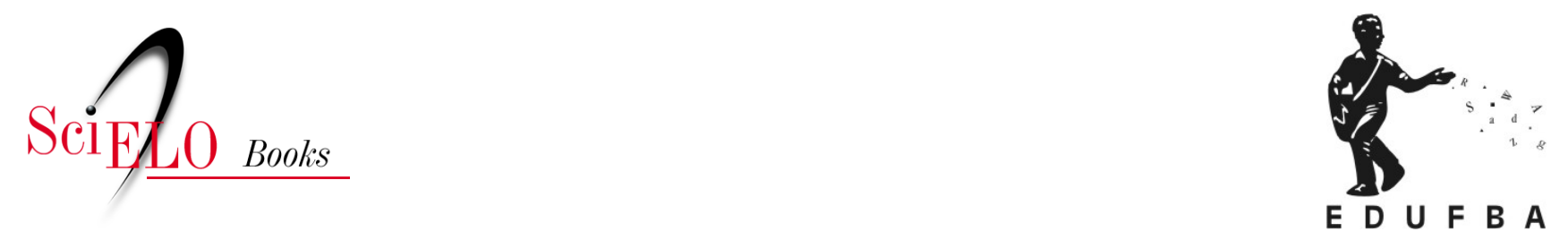

\title{
Cooperação internacional para o desenvolvimento institucionalidades e agendas em distintos contextos econômicos e políticos
}

Elsa Sousa Kraychete

\section{SciELO Books / SciELO Livros / SciELO Libros}

KRAYCHETE, E.S. Cooperação internacional para o desenvolvimento: institucionalidades e agendas em distintos contextos econômicos e políticos. In: IVO, A.B.L., ed. A reinvenção do desenvolvimento: agências multilaterais e produção sociológica [online]. Salvador: EDUFBA, 2016, pp. 229-268. ISBN: 978-85-232-1857-7. https://doi.org/10.7476/9788523218577.0007.

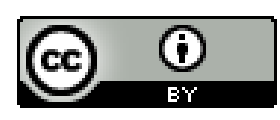

All the contents of this work, except where otherwise noted, is licensed under a Creative Commons Attribution $\underline{4.0 \text { International license. }}$

Todo o conteúdo deste trabalho, exceto quando houver ressalva, é publicado sob a licença Creative Commons Atribição 4.0. 


\section{COOPERAÇÃO INTERNACIONAL PARA O DESENVOLVIMENTO \\ INSTITUCIONALIDADES E AGENDAS EM DISTINTOS CONTEXTOS ECONÔMICOS E POLÍTICOS ${ }^{1}$}

Elsa Sousa Kraychete

A emergência da cooperação internacional para o desenvolvimento como uma política de Estado é parte das estratégias geopolíticas, cujos desdobramentos definiriam o lugar que as nações do centro e da periferia ocupariam no cenário mundial nas décadas seguintes ao desfecho da Segunda Guerra. A retomada das relações comerciais e de investimentos com as economias europeias, nessa conjuntura, era imperiosa para a consolidação da hegemonia mundial americana. De igual importância eram as relações de países do centro com países periféricos para além dos marcos do sistema colonial.

No decorrer da guerra, as economias europeias fortaleceram as relações bilaterais como o principal meio de realização do comércio externo. Aos Estados Unidos, detentores de 1/5 das exportações mundiais, interessava o multilateralismo, como, sob a sua influência direta, ficou estabelecido em Bretton Woods. A organização de uma econo- 
mia aberta em bases multilaterais era crucial para as estratégias empresariais americanas, mas de difícil aceitação na Europa. A manutenção do superávit comercial americano acumulado no período da guerra exigia o aumento das importações europeias, afetadas pela diminuição da produção e supervisão estatal das transações econômicas internacionais. Ocontrole sobre o uso de cambiais, associado à inconversibilidade da moeda em países de economia forte, orientavam as importações quanto às prioridades e ao volume, o que constituía limites para o aumento das relações comerciais com os Estados Unidos. A defensiva política econômica praticada na Europa orientava na direção do fortalecimento do capitalismo com bases nacionais, em sentido contrário ao de uma economia dirigida pelos princípios do multilateralismo. (BLOCK, 1989)

As debilidades internacionais do capitalismo europeu, que corroíam suas divisas monetárias, pressionavam suas economias em duas direções: reduzir as importações em dólares, para diminuir o déficit nessa moeda, e reorganizar o comércio em bases bilaterais e relações coloniais. Ambas as alternativas contrariavam os interesses da economia americana na busca do mercado mundial. A Europa, mesmo com as dificuldades decorrentes da guerra, continuava sendo o principal destino para os produtos manufaturados americanos, e a retração nesse fluxo impactaria negativamente esse produto. A retomada do comércio com suas colônias e ex-colônias - a Europa ofertando produtos manufaturados em troca de matérias-primas -, se consolidada, restringiria a área aberta ao livre comércio. (BLOCK, 1989) Cabe registrar que o comércio entre a URSS e vários países europeus era realizado na forma bilateral, constituindo mais um foco de preocupações aos defensores do multilateralismo. Em realidade, segundo Biel (2007, p. 130), trata-se da prática do "[...] multilateralismo por um lado e a tolerância de factos de certas relações neocoloniais bilaterais por outro." ${ }^{2}$

Os planejadores estadunidenses percebiam o perigo dos desequilíbrios no comércio externo para a economia dos EUA. Seguindo com informações trazidas por Block (1989, p. 128), a diminuição das reservas em ouro e a finalização dos fundos da United Nations Relief 
and Rehabilitation Administration(UNRRA) tornava mais difícil o financiamento continuado do superávit americano, deixando como alternativa aos países deficitários reduzir as compras em dólar. Em meados de 1947, as exportações americanas começaram a diminuir, confirmando previsão do Comitê Coordenador de Alto Nível dos Departamentos de Estado, Marinha e Defesa. O Comitê anunciou ainda que, nas bases em que se desenvolvia o comércio internacional, a demanda mundial era insustentável. Sem mudanças nos termos da equação comercial, as previsões apontavam para recessão da economia dos Estados Unidos, com efeitos danosos sobre os níveis do produto e do emprego. Como saída, o Comitê "[...] propôs um grande programa de ajuda norte americana para o financiamento da continuação de um alto nível das exportações dos Estados Unidos." ${ }^{\prime 3}$ (BLOCK, 1989, p. 130) Essa proposição constitui o argumento econômico para a implementação do Plano Marshall: financiar o superávit das exportações americanas.

Para melhor apreender a concepção e a implementação do Plano Marshall, no entanto, é preciso agregar o cenário político que desaguaria na Guerra Fria. A conjuntura política foi determinante para que o Plano fosse aprovado pelo Congresso americano. A influência da URRS sobre a Europa, em desassossego social e clamando por reformas, era evidente. Os partidos de esquerda gozavam de grande prestígio associado às lutas de resistência ao fascismo. A permanência do Partido Trabalhista no poder na Grã-Bretanha, o fortalecimento dos partidos comunistas que, em coalisão com outras forças de esquerda, chegavam ao poder na Itália e na França e a luta que se desenrolava na Grécia demonstravam o prestígio da esquerda naquele momento. No final da década, em 1948, os comunistas passaram a governar a Tchecoslováquia. Esses acontecimentos punham em alerta os defensores europeus da ordem liberal, mas sem condições de reação frontal imediata, seja pela situação econômica em seus países, seja pelos descréditos acumulados, em grade parte, pelas políticas econômicas implementadas desde a crise de 1930. A fragilidade econômica da maioria dos países impedia a radicalização dos capitalistas no enfrentamento dos partidos e sindicatos dos trabalhadores. 
Os argumentos para o início da Guerra Fria ainda encontravam apoio em fatos para além das fronteiras europeias. Na Ásia, a Revolução Chinesa (1949) e as lutas que desembocaram na Guerra da Coréia (1950-1953), resultando na divisão entre Coréia do Sul e Coréia do Norte, somavam-se com as preocupações das principais nações do Ocidente quanto ao avanço do socialismo e fortaleciam a ideia de intervenções políticas que extrapolassem a via econômica para o estabelecimento do comércio com as regras do multilateralismo.

É também parte desse contexto a articulação de países subdesenvolvidos da Ásia e da África, os quais, por iniciativa dos governos de Birmânia, Ceilão, Índia, Indonésia e Pasquitão, realizaram, em 1955, a Conferência de Bandung. ${ }^{4}$ Congregando um grupo heterogêneo quanto aos alinhamentos políticos com as duas grandes potências, essa articulação serviu de base para o Movimento dos Não Alinhados, lançado em Belgrado em 1961. Esse grupo buscava manifestar-se conjuntamente nos foros internacionais, especialmente no inteiror da $\mathrm{ONU}$, que questiona as desigualdades reforçadas pelas políticas desenvolvimentistas.

É nessa conjuntura que tem início a institucionalização da Cooperação Internacional para o Desenvolvimento (CID). Até o final da Segunda Guerra, as ações cooperantes eram pontuais e voltadas para atender a eventos tomados como conjunturais. Segundo Lancaster (2007), os Estados Unidos não teriam tomado as iniciativas nessa direção não fosse a competição entre os ideários socialista e capitalista, que deram inicio e alimentaram a Guerra Fria.

A partir desse pano de fundo, este capítulo articulaas noções de desenvolvimento e cooperação internacional de forma a explicitar agendas caraterísticas de contextos hitóricos distintos. As institucionalidades que sustentam a formulação e a implementação de políticas cooperantes também são contermpladas. O texto está organizado em cinco partes, incluídas esta introdução e a conclusão. A parte dois trata do Plano Marshall e da Aliança para o Progresso, marcos de programas desenvolvidos pelos Estados Unidos sob a rubrica de cooperação internacional. A terceira parte apresenta e analisa o emergir de formulações 
intelectuais e a institucionalidade que sustentam os programas e projetos cooperantes. Na quarta parte, é explicitada a agenda da cooperação internacional a partir da crise dos anos 1970, tomando-se por base documentos produzidos por organizações interestatais.

\section{O Plano Marshall e a Aliança para o Progresso: primeiras experiências da cooperação internacional sob o manto da Guerra Fria}

A geopolítica que justificou a Guerra Fria é responsável pelas iniciativas dos Estados Unidos em promover programas de cooperação internacional de forma continuada, deixando para trás a época das ações pontuais, movidas por interesses diplomáticos específicos, tópicos e ações humanitárias diante de calamidades, para se constituir como um conjunto de políticas que compreende interesses econômicos e políticos de forma conjunta. Vários autores (BLOCH, 1989; HAYTER, 1971; LANCASTER, 2007; SAUNDERS, 2008) estão de acordo que os Estados Unidos não teriam iniciado seus programas de ajuda internacional senão sob as disputas da Guerra Fria.

O Plano Marshall e a Aliança para o Progresso, dois abrangentes programas idealizados para atender a países europeus e latino-americanos, respectivamente, são exemplos de como foi sendo construído o ideário e as estruturas organizacionais que passaram a orientar e a implementar a ajuda externa americana nas décadas seguintes.

O Plano Marshall foi lançado em 5 de junho de 1947, em discurso do general George Catlett Marshall, então secretario de Estado do presidente Truman, que ocupou a chefia do estado-maior do exército norte-americano durante a guerra. O discurso reforçava o chamamento ideológico já anunciado por Truman em março daquele mesmo ano. Mesmo com as recomendações do Comitê Coordenador de Alto Nível dos Departamentos de Estado, Marinha e Defesa quanto aos riscos de depressão econômica se medidas de ajuda à Europa não fossem tomadas, a mensagem de Truman, ao se dirigir ao Congresso, em março de 1947, solicitando ajuda especial à Grécia e 
à Turquia, ressaltava os aspectos políticos, exaltando os ânimos para a escolha entre o totalitarismo e a liberdade. Segundo Block (1989, p. 131), a mensagem "[...] afirmava que os Estados Unidos interviriam do lado da liberdade onde quer que fosse necessário."5 Essa mensagem enuncia o tom que a Doutrina Truman assumiria. $O$ acento nos aspectos políticos, por um lado, buscava convencer os congressistas e o público em geral - ambos com ressalvas sobre a intervenção externa norte-americana - a respeito da importância de ações frente à ameaça externa. Por outro lado, ela sinalizava para as forças liberais europeias a disposição de intervenção dos Estados Unidos contra as forças de esquerda. Esse seria o sentido que passava a marcar o discurso da política externa americana no período da Guerra Fria.

Em dezembro desse mesmo ano, o governo enviou ao Congresso o projeto de lei relativo ao European Recovery Program, que, aprovado, passou a ser conhecido como Plano Marshall. Já que ainda não haviam sido debeladas as resistências dos congressistas quanto à importância de os Estados Unidos intervirem em assuntos externos, o projeto encontrou resistências. Em busca do convencimento, o governo retomou o discurso da ameaça e requereu não apenas a aprovação do Plano Marshall como também de um programa de treinamento militar universal. (BLOCK, 1989, p. 136) Totalitarismo, liberdade e segurança são noções que passam a sedimentar a cooperação internacional.

Aprovado o Plano em abril de 1948, foi criada uma agência responsável por sua administração, a Economic Cooperation Administration (ECA), desvinculada do Departamento de Estado e respondendo diretamente ao presidente. Por essa via, vão se estabelecendo vínculos entre o aparelho de estado e corporações privadas (empresas e fundações empresariais), passando a ser comum recrutarem-se empresários para dirigir órgãos governamentais ecarregados da cooperação internacional. A presença de representantes de empresas em comitês consultivos passou a ser prática corrente. O primeiro diretor da ECA foi Paul Gray Hoffman, empresário ligado ao Partido Republicano. ${ }^{6}$ Esse formato organizacional sinaliza para um dos traços da institucionalização da cooperação internacional: criar órgão específico de coordena- 
ção e parceria entre governos e setor privado. Na Europa, com a finalidade de promover a cooperação entre os países membros e gestão dos recursos do Plano Marshall, foi criada, em 1948, a Organização para a Cooperação Econômica Europeia (OCEE), nesse caso, já com formato interestatal.

No decorrer dos quatro anos de vigência do Plano, foram distribuídos 13,5 milhões de dólares, sendo os principais beneficiários Grã-Bretanha (26\%), França (23\%) e Alemanha (10\%). (ATTAR, 2009) O Plano Marshall, no entanto, é mais que a transferência de recursos para a reconstrução da Europa. Ao fincar raízes no multilateralismo, os acordos bilaterais punham obstáculos à continuidade do comércio bilateral entre países europeus e suas colônias ou ex-colônias, o que colocava empecilhos ao amplo acesso a matérias primas pelos Estados Unidos em países na órbita do poder europeu.

Em 20 de janeiro de 1949, o presidente Truman, em sua mensagem ao Congresso, anunciou quatro pontos que orientariam a política externa americana: a continuidade do apoio à Organização das Nações Unidas; o seguimento do Plano Marshall como apoio à reconstrução da Europa; a criação de uma organização (que veio ser a OTAN) de defesa para fazer frente à ameaça soviética; e a ajuda técnica aos países insuficientemente desenvolvidas. Esse último item, o Ponto IV, como passou a ser conhecido, tem como fio condutor a noção de desenvolvimento, articulada com o subdesenvolvimento. Em síntese, o Ponto IV destacava que grande parte da humanidade vivia na pobreza, em condições próximas à miséria, com alimentação inadequada e doenças. A permanência desse quadro, completava, constituía uma ameaça ao mundo desenvolvido. Anunciava também que as nações desenvolvidas, os Estados Unidos em especial, dispunham de um arsenal de técnicas industriais e conhecimentos científicos que, se mobilizados e disponibilizados por meio da cooperação técnica, levariamo desenvolvimento aos países atrasados. Além do chamamento à colaboração de outros países desenvolvidos, Truman estendia o convite aos empresários, ao capital privado, para, em conjunto, pôr os programas em marcha. (ESCOBAR, 1996; RIST, 2002) 
Pela primeira vez, as noções de desenvolvimento e subdesenvolvimento passam a compor a política externa americana. Superar o subdesenvolvimento é bandeira que será abraçada não apenas pelos Estados Unidos, como pela ONU e outros países desenvolvidos, quando da formulação de suas diretrizes e ações cooperantes. Quatro anos após o final da guerra, a geografia do poder mundial já se configurava com outros contornos, demandando a ampliação do discurso geopolítico. As economias europeias, embora ainda não estivessem plenamente recuperadas, avançavam sob os efeitos do empréstimo aos britânicos e das transferências via Plano Marshall, bem como das negociações em torno da conversibilidade das moedas e da ativação comércio bilateral. As importações europeias de produtos americanos reagiam. Segundo Block (1989, p. 169):

Depois dos primeiros anos do Plano Marshall, os líderes da maioria dos países da Europa Ocidental estavam dispostos a daptar-se à meta norte americana de uma economia mundial multilateral, soba condição que não fossem demasiado elevado os custos internos dessa adaptação.

A incorporação da noção de subdesenvolvimento, par a par com a de desenvolvimento, no discurso da cooperação internacional, atende a motivações econômicas e políticas. Atende à geopolítica da desarticulação do sistema colonial, às implicações no sistema de representação internacional surgido em Bretton Woods (1944) e em São Francisco (1945), como também a disputas por novos mercados para produtos industrializados e fontes de abastecimento de matérias-primas para as economias industrializadas.

Em seus desdobramentos, a cooperação orientada pela Doutrina Truman indicava a possibilidade de implementar ações com investimentos privados complementados com recursos públicos. Para viabilizar esse arranjo, o governo mobilizava empresários para realizarem investimentos em países do Terceiro Mundo, especialmente relativos àmontagem de infraestrutura produtiva. Compunham as iniciativas 
orientadas para o desenvolvimento dos países subdesenvolvidos o acesso a crédito a ser concedido pelo Export-Import Bank (EximBank) ${ }^{8}$ e a cooperação técnica com investimentos públicos, de forma bilateral ou multilateral, por meio das organizações internacionais interestatais.

Para viabilizar o intercâmbio de conhecimento técnico, foi criado, no Departamento de Estado, em 1950, a Tchenical Cooperation Administration (TCA), com o objetivo de administrar os programas de cooperação técnica inspirados no Ponto IV.

A Aliança para o Progresso, lançada pelo governo Kennedy em 1961, em Punta Del Este, constituiu a principal peça da política externa dos Estados Unidos para a América Latina. Há muito, governantes latino-americanos reivindicavam de governos americanos planos de assistência à região. A Operação Pan-Americana, lançada no governo Juscelino Kubitschek, é um exemplo. O Brasil, especialmente, esperava ser recompensado pela participação na guerra, quando não só enviou tropas ao front, como cedeu seu território como base militar. A importância do Programa completa seu sentido quando se analisa o cenário polarizado mundialmente, o que, no continente americano, ganhava concretude com a Revolução Cubana.

As noções orientadoras da Aliança tinham raízes fincadas na teoria da modernização e apontavam para a importância de ações capazes de mudar a estrutura produtiva, com apoio à industrialização e mudança da propriedade da terra, urbanização, construção de moradias populares, além de medidas para combater o analfabetismo e melhoria da saúde. Também orientava no sentido de mudanças nas burocracias estatais, com a formação de quadros técnicos e construção de indicadores capazes de medir o desenvolvimento de cada país e compará-lo com o de outros países. (ESCOBAR, 1998; MORAES, 2006)

Para apoiar a implementação do programa, estavam previstos vinte bilhões de dólares a serem aplicados em dez anos, tempo de vigência previsto. Sua administração ficou a cargo da United States Agency for International Development United (USAID), criada em novembro de 1961. A USAID, até o momento, coordena os programas de ajuda externa americana. 
É parte da Aliança os Peace Corps, um programa que mobilizava jovens para atuar em comunidades pobres de vários países, realizando trabalhos voluntários. O discurso que sustentou ideologicamente esse programa buscava dissipar os vínculos entre os Corpos de Paz e a política externa americana no contexto da Guerra Fria, para manter sintonia com a tradição missionária norte-americana, que orientava as missões religiosas no exterior. Os missionários não fariam parte de uma missão oficial dos EUA. Os vínculos políticos, no entanto, ficam claros quando o parlamento inclui emendas ao projeto inicial: "[...] investigação pelo $\mathrm{FBI}$ dos candidatos a voluntários; treinamento dos voluntários em filosofia e táticas comunistas, e o juramento dos selecionados afirmando que não advogariam a derrubada do governo americano." (AZEVEDO, 2007, p. 68) Em que pese essa sintonia, a administração dos recursos do programa e o recrutamento dos voluntários não ficariam a cargo das Igrejas. Também não ficou sob a guarda da recém-criada USAID. A coordenação dos Corpos de Paz, segundo Azevedo (2007), ficou subordinada diretamente ao presidente.

\section{A institucionalização da cooperação internacional para o desenvolvimento}

A institucionalidade que garante a coesão política da cooperação internacional envolve inter-relacionamentos entre organizações internacionais interestatais, estados nacionais e iniciativa privada (fundações empresariais, think tanks e ONGs, igrejas), assumindo formas variadas a depender dos contextos políticos e históricos. A parceria entre tais organizações se consolida a partir da montagem de agendas de pesquisas (com forte apoio de financiamentos governamentais), cujos resultados vão impactar no ensino das ciências sociais - economia e sociologia, especialmente -, em universidades de todo o mundo, e influenciar governos que passam a perseguir mudanças na ordem mundial definida pelas noções de desenvolvimento e subdesenvolvimento. Para atingir esse intento, é necessário construir consensos políticos e intelectuais. Nessa direção, são também fortalecidas as pesquisas sobre 
a chamada administração científica e o planejamento estatal, como ferramentas para lidar com os conflitos entre classes sociais e entre as nações.

\section{Empreendimentos intelectuais para nortear a cooperação internacional: da modernização ao alívio da pobreza}

Diferentemente dos estudos até então realizados, voltados para a investigação das origens do capitalismo na Europa e do progresso da economia dos Estados Unidos, as investigações iniciadas nesse momento priorizam os estudos sobre desenvolvimento, noção pareada com a de subdesenvolvimento, termos que passam a marcar a retórica desenvolvimentista a partir da segunda metade do século XX. Desse esforço emerge uma estrutura conceitual que pretende iluminar a trajetória que levaria todos os povos a alcançarem a modernidade. $\mathrm{O}$ horizonte era universalizar, em marcha guiada pela ideia do progresso, os níveis de industrialização, urbanização, mecanização da agricultura, consumo e bem-estar alcançados pelas nações desenvolvidas. (ESCOBAR, 1998; MORAES, 2006)

\section{A modernização para superar o subdesenvolvimento}

Em largos traços, as investigações foram orientadas para identificar e comparar os diferentes "estágios de desenvolvimento das nações", que passam a ser lidos sob a ótica da dicotomia entre moderno e tradicional, conforme as proposições de WaltRostow e TalcotParsons, pioneiros construtores da matriz conceitual e metodológica das teorias do desenvolvimento e da sociologia da modernização. Ambas as disciplinas nortearão os esforços intelectuais e governamentais que visavama iluminar a trajetória e a realizar reformas capazes transformar os países atrasados em modernos e desenvolvidos. (ESCOBAR, 1998; MORAES, 2006; RIST, 2002)

A identificação dos "estágios de desenvolvimento" de cada país com base em indicadores essencialmente econômicos - PIB, PND, nível de renda, padrão de consumo, entre outros - vai permitir não ape- 
nas caracterizar cada um dos países como fornecer elementos para cotejar o desenvolvimento entre as nações. A escolha de indicadores para as comparações possibilita a definição de metas a serem atingidas em espaços e tempos definidos pelos planejadores. É característica dessa época a montagem, no aparelho de Estado, de um conjunto de órgãos responsáveis por diagnosticar e planejar, de forma a orientar os capitais para áreas promissoras de valorização e acumulação, como também direcionar as intervenções diretas do Estado em setores produtivos e realizar investimentos nas áreas de educação e saúde, entre outras.

Para Mészaros (2004), esse empreendimento estatal combina ações políticas e econômicas e tem por base os princípios da "administração científica", que, ao colocar o Estado como árbitro entre as classes, visava ao estabelecimento do consenso entre partes contraditórias. Completa o autor:

Dentro deste quadro, as ideologias de consenso, política institucionalmente sustentadas, têm um peso e um poder de persuasão muito maiores do que qualquer outro apelo direto - em nome da ciência ou de qualquer outra coisa - a que os indivíduos particulares e os grupos sociais 'revolucionem sua atitude mental' para que haja uma 'cooperação fraterna', apelo este que, deixado por sua própria conta,está fadado a permanecer confinado ao plano do mero pensamento veleitário (MÉSAROS, 2004, p. 145)

As iniciativas cooperantes das organizações internacionais tinham, entre seus pressupostos, o estabelecimento de consensos quanto aos rumos do desenvolvimento, o que envolvia alinhar as perspectivas entre as elites e os governantes, interna e externamente. As "missões" de tais organizações a países do Terceiro Mundo, que precediam os acordos sobre projetos de ajuda e de concessão de créditos, traziam, entre suas condicionalidades, a adoção do planejamento.

Cumpridas mais de duas décadas de orientações das organizações internacionais aos cursos universitários - para, dentro de padrão definido, introduzir o estudo do desenvolvimento em seus currículos e 
formar planejadores que projetassem, no governo, o desenvolvimento de seus respectivos países, ofertassem créditos, orientassem sobre as etapas a serem cumpridas para que os programas de ajuda ao desenvolvimento fossem operacionalizados -, a metáfora do espelho, na qual a economia e a sociedade dos Estados Unidos eram tomadas como o ideal a ser atingido, já não podia ser usada sem senões.

\section{O alívio da pobreza como eixo do desenvolvimento 9}

Os anos 1970, a começar pelo desmonte do sistema financeiro organizado em Bretton Woods, seguido por indicadores macroeconômicos preocupantes nos países desenvolvidos, punham fim às décadas de crescimento continuado de países da Europa e do Japão, reconstruídos dos efeitos do conflito, e dos Estados Unidos, que se mantiveram na liderança por longo período. As tentativas de aplicar as políticas praticadas desde o pós-guerra já não respondiam satisfatoriamente a ponto de reverter o quadro econômico nessa parte do mundo. Por outro lado, as desigualdades entre o desenvolvimento das nações, ao contrário do anunciado no período anterior, não apontavam em outra direção. Tem início uma nova era no repensar do desenvolvimento socioeconômico.

Em um mundo entrecortado pelas disputas da Guerra Fria, destaca-se o surgimento de países desmembrados do sistema colonial, que se inseriam no sistema interestatal internacional, como também de um grande número de países subdesenvolvidos que buscavam modificar os termos de suas inserções internacionais. Foram muitos os intentos institucionais para propor uma nova agenda desenvolvimentista e uma regulação condizente. Primeiro, seria necessário desmontar o arcabouço teórico que sustentou o crescimento econômico de parte das nações e as crenças de que o desenvolvimento era motor para se alcançar a igualdade territorial e social. O primeiro movimento nessa direção veio de forte ofensiva teórica às políticas econômicas e sociais de corte keynesiano, que já repercutiam no meio acadêmico, mas ainda não exerciam grande influência sobre as políticas governamentais. O Banco Mundial já inseria, em seus documentos, menções à doutrina 
neoliberal, mas sem apresentar um discurso articulado que configurasse um novo ideário de desenvolvimento.

O Relatório sobre o Desenvolvimento Mundial (1991), editado pelo Banco Mundial, apresenta a noção de desenvolvimento que norteará ações das organizações intergovernamentais internacionais e dos governos nacionais na implementação de políticas que visem ao crescimento econômico e ao desenvolvimento. A noção de desenvolvimento expressa nesse documento é, em grande medida, conduzida de forma a colocar a reforma das instituições como uma condição necessária para que os países reencontrem a trajetória do desenvolvimento. O Relatório sobre o Desenvolvimento Mundial do ano anterior tratou do tema da pobreza, apresentando diagnóstico sobre o estado da pobreza no mundo e diretrizes para a definição de programas e projetos visando à sua minoração. Os termos colocados para conduzir o desenvolvimento, articulado com políticas de minoração da pobreza, vão também orientar as redefinições na cooperação internacional para o desenvolvimento. Os princípios básicos nessa noção de desenvolvimento são: investir no ser humano, proporcionar ambiente favorável ao empreendedorismo, integrar as economias nacionais com a dinâmica mundial e garantir a estabilidade macroeconômica. (WORLD BANK, 1991, p. 1)

A interação entre governos e mercados é o arranjo institucional central para a condução do desenvolvimento. Nesse início dos anos 1990, o papel a ser desempenhado pelo Estado é reconsiderado, não no sentido de retomada do seu desempenho, como é traçado pelo modelo desenvolvimentista, mas já tomando alguma distância do Estado minimalista tal como foi definido nos anos 1980. Reafirma o papel dos mercados para organizar a produção e distribuição de bens e serviços, mas considera que os mercados não funcionam no vácuo - necessitam da estrutura jurídica e normativa que somente os governos podem oferecer. (WORLD BANK, 1991, p. 1) Embora essa nova formulação seja distinta da que vigorou nos anos 1980, a primazia na condução do desenvolvimento continua sendo do mercado, pois o Estado secunda-o, oferecendo condições para que aquele possa atuar mais eficazmente. 
As dificuldades de reerguer as economias desmembradas do bloco soviético, a crise fiscal dos Estados dos países desenvolvidos e a desagregação de Estados em países da periferia, exigindo ações de emergência, levam o Banco a aprofundar a discussão sobre o papel das instituições. A partir da segunda metade da década de 1990, o discurso institucional apresenta nuances que já anunciavam alguma inflexão, na direção de fortalecer as instituições. Os relatórios sobre o desenvolvimento mundial correspondentes a 1997, sob o título O Estado num Mundo em Transformação, e o relativo ao ano de 2001, que desenvolve o tema Instituições para os Mercados, voltam ao tema para afirmar a necessidade de reformar o Estado e fomentar instituiç̧ões inovadoras e competitivas para respaldar os mercados.

A orientação para os governos é que eles deveriam ajustar suas funções à capacidade, de forma a se tornarem mais eficientes e capazes de estabelecer bons fundamentose ofertar apenas serviços básicos. É recomendando também que o Estado atue em parceria com o poder judiciário e o legsilativo para promover reformas liberalizantes que venham conceber e implementar novos modos de regulação.

A última recomendação é a aproximação entre o Estado e o público: "Os governos são mais eficientes quando escutam as empresas e os cidadãos e trabalham em parceria com eles na decisão e implementação das políticas." (WORLD BANK, 1991, p. 11)

Para respaldar os mercados, as instituições devem contribuir para alargar as oportunidades de mercado, observando os custos de transação, decorrentes da falta de informação adequada e dos problemas de definição e respeito aos direitos de propriedade. (WORLD BANK, 1991, p. 3)

O ajuste institucional sob a ideia de boa governança propõe a adequação das instituições às exigências da conjuntura econômica e política. A boa governança deve garantir, segundo as diretrizes do Banco Mundial, o funcionamento de uma economia de mercado, em que os direitos de propriedade sejam estáveis, os contratos sejam cumpridos e que haja transparência das práticas institucionais. O Estado e o mercado são levados a praticar ações com vistas ao estabelecimento 
de parcerias entre si, como também a atuar de forma capaz de estabelecer pactos com a sociedade civil. Esse enfoque orienta na direção de mudanças internas nas instituições e de emergência de novos arranjos interinstitucionais. Nos desdobramentos para a formulação de políticas, a ideia é que os mercados e os governos atuem como parceiros e, juntos, promovam o aprimoramento institucional para implementar reformas que venham a conceber e a conduzir novos modos de regulação e também estabelecer os limites decorrentes da explicitação dos conflitos.

Desde a década anterior, o tema pobreza vinha sendo introduzido em documentos de organizações internacionais e de governos nacionais, mas sem que fossem explicitadas políticas com vistas a lidar com essa questão de forma integrada, pois prevaleciam ações pontuais. Assim, depois de reconhecer que os programas de ajustes estruturais levaram ao aumento do número de pobres, o Banco Mundial recomenda que os governos não devem esperar a volta do crescimento econômico para que as diferenças deixem de existir. Em paralelo, deveriam os governos atuar na área social, com políticas estrategicamente orientadas de forma a seguir duas grandes diretrizes:

[...] o meio mais eficiente de obter avanços rápidos e politicamente sustentáveis na qualidade de vida dos pobres tem sido a adoção de uma estratégia de dois elementos. O primeiro elemento dessa estratégia é a busca de um modelo de crescimento que garanta o uso produtivo do bem mais abundante entre os pobres - o trabalho. O segundo elemento é o provimento amplo de serviços sociais básicos aos pobres, sobretudo de educação primária, assistência médica básica e planejamento familiar. O primeiro componente cria oportunidades; o segundo capacita o pobre a tirar proveito das oportunidades. (WORLD BANK, 1990, p. 3)

Ressalta ainda

[...] dois fatores importantíssimos que determinam a pobreza: o acesso a oportunidades de auferir renda e 
a capacidade de reação. Se as famílias tiverem oportunidades seguras de usar proveitosamente sua mão de obra e se seus membros forem capacitados, instruídos e saudáveis, certamente estará assegurado um padrão de vida mínimo e a pobreza desaparecerá. Se não existirem essas oportunidades e se o acesso aos serviços sociais for limitado, o padrão de vida será inaceitavelmente baixo. (WORLD BANK, 1990, p. 39)

A noção de desenvolvimento humano do PNUD completa a noção apresentada pelo Banco, e apresenta o seu conceito articulado por: equidade (igualdade de oportunidades para todas as pessoas na sociedade), caráter sustentável (de tais oportunidades, de uma geração para a próxima) e oportunidade e empoderamento (das pessoas, de modo que elas participem - e se beneficiem - do processo de desenvolvimento). (PNUD, 1992, p. 6) Sobressai dessa noção de desenvolvimento humano a ideia de igualdade de oportunidades, que proporcionaria o acesso dos indivíduos aos bens e serviços básicos compensatórios das deficiências individuais. Igualadas as oportunidades, os indivíduos estariam capacitados para competir no mercado com igualdade de condições.

A capacidade dos indivíduos é a segunda noção que compõe a ideia de desenvolvimento sustentável. As oportunidades equânimes na capacitação dos indivíduos permitem que eles adquiram melhores condições de colocação no mercado competitivo. A igualdade de oportunidades e a ampliação das capacidades constituem elementos-chave para que os indivíduos alcancem nível adequado de bem-estar, objetivo maior do desenvolvimento humano. O bem-estar seria uma situação que os indivíduos podem alcançar a partir de sua inserção no mercado e no consumo de bens e serviços que satisfaçam às suas necessidades básicas.

Nessa noção de bem-estar não está em questão a desigualdade. As desigualdades de renda e de riqueza são tomadas como um dado posto pela realidade. Cabe ao pobre, na condição de consumidor, ade- 
quar o seu padrão de consumo, em quantidade e em qualidade, aos produtos básicos ofertados.

A escassez de recursos, sobretudo nos países periféricos, segundo o PNUD, recomenda que as políticas sociais nesses espaços sejam orientadas a partir da eleição de grupos-alvo, aos quais deveriam ser providos serviços sociais básicos - educação, saúde, nutrição, saneamento básico - de modo a suprir suas carências. O preenchimento dessas carências teria como objetivo, por um lado, a ampliação das capacidades dos indivíduos, igualando-os com vistas à competição no mercado e, por outro, seria um meio para elevar a eficácia dos recursos escassos.

A eficácia e a eficiência das políticas são avaliadas a partir do objetivo de diminuir a pobreza, de tal maneira que se tornem eficazes as políticas, os programas e projetos que a minimizem efetivamente, e eficientes os que conseguemfazê-lo com custos mais baixos.

Esse objetivo só pode ser alcançado de modo eficiente por meio da concentração (focalização), isto é, de programas e projetos que, na verdade, venham a beneficiar os pobres, com um mínimo de escoamento para outros grupos populacionais. A concentração supõe seletividade, meio pelo qual costumam ser mais eficientes os mecanismos de seletividade territorial e de autosseletividade. (PNUD, 1992, p. 174)

A eleição de grupos-alvo orienta, metodologicamente, no sentido de que a pobreza possa ser medida de maneira absoluta e de maneira relativa. A pobreza absoluta seria a que engloba o indivíduo ou o grupo familiar cuja renda é apenas suficiente para adquirir uma cesta de bens e serviços que o ser humano requer como mínimo para sobreviver. Já a pobreza relativa seria constituída pelos indivíduos cujo nível de renda está abaixo da metade do rendimento mediano de outros grupos de indivíduos ou de outra sociedade.

A noção de pobreza absoluta comporta a demarcação de linha de indigência e linha de pobreza. A pobreza absoluta tem por base um nível de renda necessário para a estrita reprodução do indivíduo ou do grupo familiar. Os indivíduos ou grupos familiares abaixo dessa linha são classificados entre os que vivem em situação de pobreza extre- 
ma. (WORLD BANK, 1990). Para os indivíduos que vivem em estado de pobreza absoluta, são prescritos programas de transferências de renda - distribuição de alimentos, programas de bolsas para fins diversos, entre outros - que os ajudem a ultrapassar essa fronteira. Já para os pobres que conseguiram vencer a linha de indigência, as recomendações recaem sobre a distribuição de ativos aliada ao funcionamento do mercado. Para atender a esses pobres, cabe aos governos nacionais traçar políticas que visem ao seu ingresso nos mercados de terras e de crédito, ativos capazes de capitalizar os indivíduos, levando-os a romper as fronteiras da pobreza.

Sem explicitar as raízes da pobreza, vai sendo expressa uma agenda social na qual a questão do trabalho vai sendo progressivamente excluída. A agenda social, a partir de então, passa a ser orientada pela noção de pobreza, expressa como uma "nova pobreza", a ser enfrentada por meio da eleição de grupos-alvo, atendidos por políticas focalizadas que visem, em primeiro lugar, ao atendimento das necessidades básicas.

Compõe ainda essa noção de desenvolvimento a reconfiguração territorial como base para definir e implementar políticas sociais. Constata-se forte interferência das organizações internacionais na intervenção social, antes tida como de responsabilidade de entes nacionais, seja a partir de questões prioritárias, seja por meio de concessão de recursos financeiros específicos para aplicação em projetos socais e na ascensão do local como espaço privilegiado para execução de políticas sociais.

O consenso será o caminho recomendando para introduzir reformas destinadas a reduzir a pobreza e evitar confrontos entre pobres e não pobres. Embora muitas medidas econômicas tragam benefícios aos ricos à custa dos pobres, outras vinculam o destino de um dos grupos ao destino do outro, podendo ser apoiadas por coalizões que transcendem a linha divisória entre os que são pobres e os que não são. (WORLD BANK, 1990, p. 53)

As políticas que ajudam os pobres, mas impõem ônus aos não pobres, encontrarão resistência, quer aumentem a renda nacional, 
quer não. Os não pobres são geralmente poderosos, e exercem forte influência na política. Dar mais voz aos pobres na tomada de decisões locais e nacionais ajudaria a restabelecer o equilíbrio. Mas, como o poder político tende a refletir o poder econômico, é importante traçar políticas para reduzir a pobreza que recebam o apoio dos nãopobres, ou, pelo menos, não provoquem sua resistência ativa. (WORLD BANK, 1990, p. 54).

$\mathrm{Na}$ impossibilidade de constituir arranjos políticos que harmonizem os interesses entre pobres e não pobres, para evitar a resistência desses últimos, a proposição é adotar "[...] políticas com o menor ônus possível para maioria." (WORLD BANK, 1990, p. 55).

\section{A criação de organizações para planejar e implementar a cooperação internacional}

A Cooperação Internacional para o Desenvolvimento é instituída por extensa rede de organizações que abarca as governamentais de bases nacionais, as internacionais intergovernamentais e as não governamentais com origem em iniciativas de igrejas, empresas e cidadãos envolvidos com as temáticas do desenvolvimento. Essas organizações operam a partir de motivações específicas e iniciativas próprias,ou em parcerias com esferas governamentais, seja na concepção ou implementação de programas, seja como fonte de recursos financeiros.

A Organização para a Cooperação e Desenvolvimento Econômico (OCDE), criada em 1961, quando da dissolução da Organização para a Cooperação Econômica Europeia (OCEE), historicamente é a entidade responsável pela coordenação institucional do Sistema de Cooperação Internacional para o Desenvolvimento (SCID). No âmbito da OCDE, o Comitê de Ajuda ao Desenvolvimento (CAD) ${ }^{10}$ é o ambiente de concertação entre as agências bilaterais e multilaterais, sendo responsável pela explicitação de conceitos, diretrizes políticas e de gestão que orientam a construção de agendas comuns. Anualmente, o CAD divulga as estatísticas que retratam a cooperação dos países membros. As definições seguintes (AYLLÓN PINO, 2013; IGLESIA-CARUNCHO, 2005; MILANI, 2013; OCDE, 2008, 2011) permitem entender os tipos 
de transferências que fazem parte da cooperação internacional ao desenvolvimento, como também as modalidades de acordo com as organizações envolvidas e o tipo de relação entre doadores e receptores da ajuda.

- Ajuda Oficial ao Desenvolvimento (AOD) -Tranferência de recursos de origem pública, efetuada diretamente por agências estatais ou via organizações interestatais internacionais e organizações não governamentais a países de menor desenvolvimento. Para ser classificada como AOD as transferências precisam: (a) ter como objetivo principal a promoção do desenvolvimento econômico e o bem-estar dos países receptores; (b) concessionalidade (doação) mínima de $25 \%$ (e de $50 \%$ para "países de menor desenvolvimento", avaliados pela medida de nível de renda). São classificadas como AOD não apenas transferências financeiras como também a cooperação técnica.

- Ajuda humanitária - Doações de medicamentos, alimentos etc., em momentos de catástrofes, e perdão de dívidas concedidas a países muito pobres, são também contabilizados como AOD. Não compõem o rol da AOD a ajuda com propósitos militares, operações de paz comandadas pela ONU, gastos comprogramas de combate ao terrorismo e aplicações não pacíficas de energia nuclear, gastos com programas sociais e culturais de natureza pontual oupromotores da cultura do país doador.

- Cooperação multilateral - Praticada por organizações e fundos multilaterais constituídos com recursos aportados por várias fontes, sem que seja explicitado, especificamente, cada doador. A Organização das Nações Unidas (ONU), com seu leque de agências especializadas, e a União Europeia, cujos fundos têm origem nos estados membros, são exemplos de organizações multilaterais que atuam no âmbito da CID.

- Cooperação bilateral - Corresponde à modalidade praticada pelos países doadores, que repassam recursos públicos ou 
por meio de suas agências e bancos oficiais, ouvia instituições e organizações de sua sociedade civil. Essa forma de cooperação pode ser executada por entidades distintas, por um ministério ou agência especializada que cuida da cooperação do seu país, por entes estatais territoriais que não a União, a exemplo da cooperação praticada por unidades federativas e municípios, e por Organizações não Governamentais de Desenvolvimento (ONGD).

- Cooperação triangular - Cooperação técnica que busca acomplementaridade de recursos - capital e tecnologias -, ofertada a partir de acordo entre três países: um país desenvolvido, detendor de recursos financeiros, um país em desenvolvimento, detentor de tecnologia, e um país de menor desenvolvimento, receptor da cooperação.

- Ajuda não oficial ao desenvolvimento - Transferências de recursos realizadas por ONGD, igrejas e fundações empresariais e partidárias sem fins lucrativos, entre outras. Embora essa modalidade de cooperação não seja regulada diretamente pela OCDE, os aportes realizados por entes governamentais aorganizações dessa natureza, para fins de cooperação com países em desenvolvimento, são contabilizados como AOD do país ou organização que concedeu o recurso. Essa modalidade de cooperação vem sendo incentivada pelos Foros de Alto Nível, patrocinados pela OCDE para redefinir a agenda dacooperação para o desenvolvimento, realizados a partir dos anos 2000, como será visto em seguida.

No decorrer dos anos 1960, a institucionalização da cooperação internacional foi marcada por iniciativas no âmbito dos estados nacionais pela criação de organizações com missão específica de planejar e implementar programas cooperativos de seus respectivos países. Mesmo os países que optam por não constituir organização com essa finalidade, eles criam departamentos especializados no âmbito de um 
ministério, em geral no das relações exteriores. São exemplos de agências bilaterais criadas nos anos 1960: Agência de Cooperação Internacional Estadunidense - USAID (1961); Ministério Alemão para Cooperação Econômica e Desenvolvimento (1961):i1 Fundo de Cooperação Econômica Transoceânica do Japão (1961):12 Ministério da Cooperação Internacional da França (1961); Oficina para a Cooperação para o Desenvolvimento da Bélgica (1962); Secretariado para a Cooperação para o Desenvolvimento da Dinamarca (1962); Agência Norueguesa de Cooperação para o Desenvolvimento (1962); Agência Sueca para a Ajuda Internacional (1962); Ministério de Desenvolvimento Transoceânico do Reino Unido (1964); Agência Canadense de Desenvolvimeto Internacional (1968). (PESSINA, 2012). Essas agências desempenham destacado papel na política externa de seus respectivos países, sendo instrumentos para alinhamentos ideológicos e convergências políticas. Já se destacou, neste texto, como a foreignaid se constituiu em mecanismo-chave para a política externa americana durante a Guerra Fria.

O ordenamento internacional resultante da segunda Guerra Mundial tem, na emergência de organizações interestatais internacionais, uma de suas marcas distintivas. As organizações que surgem em Bretton Woods - Banco Mundial e FMI - e a ONU, criada na Conferência de São Francisco em 1945, assim como um conjunto de novas organizações, a exemplo dos Bancos Regionais de Desenvolvimento, ocupam lugar relevante na institucionalização da cooperação internacional para o desenvolvimento. Agências da ONU, como a Organização das Nações Unidas para a Alimentação e Agricultura (FAO), a Organização das Nações Unidas para a Educação, a Ciência e a Cultura (UNESCO), a Organização Mundial da Saúde (OMS), a Organização Internacional do Trabalho (OIT), para citar apenas as mais conhecidas, e programas como o Programa das Nações Unidas para o Desenvolvimento (PNUD) são de considerável importância na definição de agendas e na definição de diretrizes para a governança da CID.

A atuação do Banco Mundial, em seus traços mais característicos, não se confunde com as tranferências de recursos realizadas por meio dos programas da CID, (exceção para perdão de dívidas e conces- 
sinalidades em empréstimos para países com muito baixo nível de renda). No período dos ajustes estruturais comandados pelo Banco e pelo FMI, especialmente no decorrer dos anos 1990, as condicionalidades colocadas por essas organizações eram tomadas em conta para o acesso a programas da CID. Dessa forma, essas organizações participam da governança da cooperação internacional.

É possível observar que, ao longo da história, essas organizações vão se diferenciando e redefinindo seus lugares no âmbito da CID, com as multilaterais mais dedicadas a coordenar programas, enquanto as agências bilaterais cuidam dos projetos. (MILANI, 2014) O fim da Guerra Fria e o relativo descrédito em ações coordenadas por agências multilaterais abrem espaço para acordos bilaterais. As organizações multilaterais e bilaterais são centrais para a compreensão das articulações e concertações que constituem a institucionalidade da CID. ${ }^{13}$

Completam a arquitetura institucional da cooperação internacional as organizações não governamentais. Nesse conjunto, uma miríade de organizações são candidatas a se abrigaram sob a rubrica não governamental. Organizações dessa natureza não são estrangeiras aos ambientes governamentais nacionais ou internacionais, pois a Carta da ONU, em seu artigo 71, já previa que o Conselho Econômico e Social (ECOSOC) poderia, por meio de um comitê consultivo, estabelecer relações com ONGs em temas de suas competências.

Mas foi a partir dos anos 1970, no contexto da crise do sistema regulatório, que as ONGs passaram a ser convidadas pelas organizações multilaterais e bilaterais para participarem de foros nos quais a temática social era o centro. Os anos 1990, já na busca de novos arranjos institucionais de regulação da SCID, marcam uma nova fase da relação entre agentes públicos e privados com maior presença de entes não governamentais, (fundações empresariais sem fins lucrativos, entidades filantrópicas, ONGD). A partir desse momento, as reuniões, encontros e eventos conjuntos, anteriormente realizados eventualmente, tornaram-se frequentes. 
A presença de entes não governamentais passa a ser uma constante nas Conferências realizadas sob os auspícios da ONU na década de 1990. Das ONGD e entidades filantrópicas são esperadas contribuições para formular o discurso da agenda social e a reafirmação de que é possível implementar projetos com baixos custos. Repetidamente, era reafirmado que a SCID precisava ser imbuída dos valores da eficácia e eficiência das empresas, e que fundações empresariais seriam guardiãs. O vago chamamento do então secretário da ONU, Boutros Boutros-Ghali, na Rio-92, para que as empresas integrassem ações cooperantes em torno do desenvolvimento, encontra formulação mais orgânica em Davos, no Foro Econômico Mundial em 1999, quando Kofi Annan propôs o Global Compact. (ARAGÃO, 2014)

Em processo de legitimação recíproca, entes governamentais e não governamentais incentivaram as parcerias público-privadas, mesmo que os interesses e as agendas específicas não fossem, em seu todo, convergentes. As noções de eficiência e eficácia guiam a ideia da boa governance.

\section{Agendas da cooperação internacional para o desenvolvimento a partir dos anos 1970}

A crise do modelo de desenvolvimento inicada nos primeiros anos da década de 1970 repercute na agenda da cooperação internacional para o desenvolvimento de forma a propor consensos entre organizações públicas e privadas. As ideias de eficiência e eficácia aparecem como valor chave a ser perseguido pelas organizações coo-

perantes. Também passa a ser recomendado que o financiamento da cooperação internacional, anteriormente ancorado em recursos públicos, passe a buscar fontes privadas. Este item, com base nos documentos resultantes dos foros organizados pela OCDE, busca reconstuir a evolução que resulta na agenda atual. 


\section{A busca do consenso articulado a partir das ideias de eficiência, eficácia e parcerias público-privadas}

Na segunda metade dos anos 1960, em meio a muitas interrogações sobre a continuidade do crescimento das economias dos países desenvolvidos e das desigualdades entre países ricos e pobres, foram reavaliadas as trajetórias de desenvolvimento e da cooperação internacional. Em 1968, o recém-empossado presidente do Banco Mundial, Robert McNamara, recomendava avaliar a trajetória do desenvolvimento mundial. Para isso, encomenda a Lester B. Pearson a elaboração de um estudo que resultou no Parners Development, mais conhecido como Informe Pearson.

Depois de apreciações gerais sobre o desenvolvimento nas décadas seguintes à Segunda Guerra, o documento recomenda a modernização da agricultura, a continuidade da industrialização nos países em desenvolvimento, a abertura da economia desses países aos investimentos externos e o aumento das exportações. Tece críticas ao modelo de industrialização pela via da substituição de importações, orienta para a consolidação de uma economia global de livre mercado, com a expansão das empresas multinacionais e a eliminação dos obstáculos à presença de capitais externos nos mercados periféricos. (PEARSON, 1973)

Essas recomendações também vão orientar a cooperação para desenvolvimento. A análise sobre a diminuição da pobreza deixa de estar associada a questões estruturais. O enfoque que orientará as políticas focalizadas nas décadas seguintes recomenda que os programas de ajuda internacional sejam dirigidos para atender às necessidades básicas, como já registrado neste texto. Recomenda, ainda, revisão da meta de aplicação de 1\% do PND dos países ricos aos programas de cooperação com os países pobres, por considerá-la difícil de ser atendida pela maioria dos países, orientando que os países ricos deveriam, até 1975, elevar o percentual de ajuda a 0,7\% do PNB. (PEARSON, 1970, p. 12). Essa recomendação foi aceita, embora, ainda hoje, para a maioria dos países, continue como uma meta a ser atingida. Seguindo, o Informe Pearson dirige-se ao Banco Mundial e à ONU, para propor 
que, por meio da Organização Mundial da Saúde, implementem um programa de mobilização internacional de controle da natalidade. Essa recomendação será parte da agenda da cooperação no decorrer das décadas seguintes.

Segundo leitura de Cox (1973, p. 232), a cooperação internacional, a partir desse Informe,

[...] deve dirigir-se à criação das condições propícias para a expansão da economia global. A ajuda oficial complementaria o investimento privado [...]. A ajuda operaria também como um incentivo para que os governos dos países pobres adotassem políticas compatíveis com uma estratégia de crescimento através de investimento estrangeiro, um incentivo que se faria efetivo mediante uma vigilância multilateral administrada e controlada pelo Banco Mundial e FMI. ${ }^{14}$

Com o propósito de averiguar a efetividade da assistência ao desenvolvimento em programas da ONU, o PNUD, em 1969, lança o Study of the capacity of the United Nation Development System (Jackson Report), elaborado por Robert Gillman Allen Jackson. Com objetivo mais restrito, ele apresenta um diagnóstico pouco animador quanto à concorrência entre projetos no interior das agências da ONU e a ineficiente gerência desses projetos. Ressalta que, em decorrência de problemas gerenciais, $20 \%$ do total de recursos destinados à cooperação internacional resultam em perdas. Recomenda, especialmente, que os programas se alinhem aos "imperativos nacionais", como "agregados das metas nacionais" e se promova melhoria da eficiência na administração. Em seguida, passa a defender a aproximação da ONU com o Banco Mundial e o fortalecimento da burocracia encarregada da administração da cooperação internacional, a partir da montagem de uma "tecnoestrutura" que colha e sistematize informações detalhadas para subsidiar a elaboração e o monitoramento dos programas. (PNUD, 2009)

Ambos os informes apontam para inflexões no modelo de desenvolvimento e na cooperação internacional, seja no caso do Informe 
Pearson, que recomenda a abertura dos mercados dos países subdesenvolvidos e passa a indicar o caminho para a construção de uma economia global, seja no Informe Jackson quando recomenda que a cooperação passe a ser observada sob as lentes da eficiência e da eficácia. Não se pode perder de vista a conjuntura econômica e política em que foram produzidos esses documentos. A crise econômica, que se revelou para o mundo de forma mais explícita a partir dos anos 1970, já dava sinais de sua gravidade nos países centrais do capitalismo desde os últimos anos da década anterior, manifestando-se na queda da produtividade, no aumento da taxa de inflação, entre outros problemas. A regulação econômica acordada em Bretton Woods já não respondia satisfatoriamente às demandas que o momento exigia.

O alinhamento político pactuado entre as nações, no imediato pós-Segunda Guerra, se reconfigurava e passava a reclamar uma nova Ordem Econômica Internacional. Em 20 anos, a contar do final da Segunda Guerra, mais de sessenta países foram constituídos com a desarticulação do sistema colonial e passaram a compor um sistema interestatal, demandando atenção especial no contexto das disputas comandadas pela Guerra Fria. Nesse contexto, em 1964, teve lugar a inauguração da United Nations Conference on Trade Development (UNCTAD) e, na década seguinte, em 1974, surgiu a articulação "Grupo dos 77", ambos configurados como grupos de pressão no interior da ONU. É como resultado da ação desse Grupo que a ONU aprovou a Declaração por uma Nova Ordem Internacional. (ARAGÃO, 2014)

A ONU, nessa conjuntura, tornava-se um espaço de disputas entre países comandados por governos que postulavam a Nova Ordem, de um lado, e países cujos governos já realizavam proposições a partir da doutrina neoliberal, por outro. Em meio a muitas controvérsias nos anos 1980, com o cenário da crise avançado, o G-77 perde força e sua coesão é substituída por posições pragmáticas, com cada país buscando melhor defender-se frente àcrise. A ênfase no enfrentamento da crise econômica - que, a partir de princípios liberalizantes, resulta nas proposições de ajustes estruturais gestados no Banco Mundial - esvazia, em certa medida, a arena política da ONU. 
A difusão do discurso neoliberal firma as ideias de desregulamentação, privatização e concorrência, bem como os valores do individualismo. A ONU, nesse contexto, é, em grande medida, criticada, esvaziada e confrontada com as posições originadas nas organizações de Bretton Woods. Só a partir da década seguinte, já alinhada com a agenda de desenvolvimento proposta pelo Banco Mundial, a ONU volta a ocupar lugar protagônico. As coordenações de Boutros Boutros Ghali (1992-2007) e de Kofi Annan (1997-2007) são lembradas como condutoras da agenda liberal na entidade. As Conferências que marcaram essa década constituíram espaços de convergência de agendas orientadoras da proposta de desenvolvimento. Durante os anos 1990, foram realizadas as seguintes Conferências: Meio Ambiente e Desenvolvimento (Rio de Janeiro, 1992); Direitos Humanos (Viena, 1992); População e Desenvolvimento (Cairo, 1994); Desenvolvimento Social (Copenhague, 1995); Mulher e Gênero (Pequim, 1995); e Estabelecimentos Humanos (Istambul, 1996). Esse ciclo foi completado com a Conferência realizada em Durban, em 2001, articulada em torno do tema: contra o racismo, discriminação, xenofobia e intolerância.

Primordialmente de natureza intergovernamental, as Conferências, nesse ciclo, foram marcadas pela presença de ONGs, agências internacionais de cooperação não governamentais e fundações empresariais, nos denominados Foros Paralelos, realizados concomitantemente com as Conferências oficiais. Por essa época, foram cunhadas as expressões diplomacia não governamental, parceria público-privada e responsabilidade social empresarial, que põem em evidência a possibilidade de consensos entre governos e entes não governamentais para formular e implementar agendas de desenvolvimento. Vale observar que as temáticas que articulam as Conferências têm como centro temas relacionados com direitos sociais, em uma conjuntura marcada pelos questionamentos aos princípios universalizantes característicos do Welfare State. 


\section{A busca de consenso para o financiamento e a gestão da cooperação internacional}

A Conferência Mundial sobre o Financiamento do Desenvolvimento, realizada março de 2002, em Monterrey (México), inaugura a temporada de uma série de eventos que têm o financiamento e a gestão da $A O D$, para atender às metas definidas pelos Objetivos de Desenvolvimento do Milênio (ODM). Com base nas Conferências realizadas na década anterior, a ONU lançou, em 2000, oito objetivos programáticos assumidos por 191 países, a serem cumpridos em 15 anos: 1. Erradicar a pobreza e a fome; 2. Garantir o acesso ao ensino fundamentala todos; 3. Promover a igualdade de gênero e empoderar a mulher; 4. Reduzir a mortalidade infantil; 5. Reduzir a mortalidade materna; 6. Combater a Aids, a malária e outras doenças graves; 7. Garantir a sustentabilidade ambiental; 8 . Desenvolver uma parceria global para o desenvolvimento.

O chamamento aos países para aumentarem suas contribuições financeiras (AOD), de modo a permitir o atendimento das metas colocadas pelos ODM, foi um dos pontos centrais da Conferência. As estatísticas apontavam para a diminuição das contribuições dos países membros do CAD, que caíram para um montante em torno de $0,22 \%$ do PIB desses países, em 2000. A média anterior oscilava entre 0,30\% e 0,33\%. (ONU, 2002) Além desse apelo, no âmbito dos países membros da ONU, o documento final da Conferência se referiaà renovação das fontes de financiamento, a novas parcerias e harmonização de procedimentos. (ONU, 2002)

O texto seguinte traduz o espírito da Conferência nessa direção:

[...] as metas de desenvolvimento acordadas internacionalmente, inclusive as estabelecidas na Declaração do Milênio, requerem uma nova aliança entre os países desenvolvidos e em desenvolvimento. Comprometemo-nos a adotar políticas racionais, promover uma boa gestão publica em todos os níveis e respeitar o estado de direito. Também nos comprometemos a mobilizar nossos recursos internos, atrair correntes fi- 
nanceiras internacionais, fomenter o comércio internacional como motor do desenvolvimento, incrementar a cooperação financeira e técnica internacional em prol do desenvolvimento, promover um financiamento sustentável da dívida, adotar os sistemas monetários, financeiros e comerciais internacionais. (ONU, 2002 , p. 4)

Na sequência, a OCDE promoveu uma série de reuniões, os Foros de Alto Nível, para acordar sobre os meios de viabilizar o cumprimento das metas até 2015. Com esse objetivo, foram realizados quatro encontros: Foro de Roma sobre a Harmonização (Roma, 2003); Foro de Paris sobre a Eficácia da Ajuda (Paris, 2005); Foro sobre a Eficiência e a Eficácia da Ajuda ao Desenvolvimento (Acra, 2008); Foro sobre a Eficiência e a Eficácia da Ajuda (Busan, 2011).

A Conferência de Roma, segundo o documento final assinado por todos os participantes, teve como principal objetivo:

[...] harmonizar as políticas, procedimentos, e práticas operacionais das nossas instituições com as dos sistemas vigentes nos países parceiros de forma a melhorar a eficácia da assistência ao desenvolvimento e, dessa maneira, contribuir para atingir os Objetivos de Desenvolvimento do Milênio (ODM). (OCDE, 2003, p. 1)

A harmonização com o objetivo de melhorar a eficácia esta orientada para a racionalização dos trâmites burocráticos, com a simplificação dos procedimentos entre doadores e receptores da ajuda (rever o grande número de requisitos exigidos pelos países doadores, processos de preparação dos documentos, prestação de contas). É recomendada a diminuição do número de missões ao país receptor por parte dos doadores. Esses procedimentos têm gerado "[...] custos de transação improdutivos e têm limitado o crescimento das capacidades dos países parceiros." (OCDE, 2003, p. 3)

Orienta que sejam perseguidas as boas práticas apontadas "[...] pelos grupos técnicos do CAD/task force da OCDE, e pelos Bancos multilaterais de desenvolvimento (MDBs)". É recomendado também 
o envolvimento com a "[...]sociedade civil incluindo o sector privado." (OCDE, 2003, p. 3) O Fórum de Alto Nível sobre a Eficácia da Ajuda de Paris seguiu recomendação adotada em Roma, na direção de indicar os melhores procedimentos para a gestão centrada em resultados:

Neste Fórum de Alto Nível sobre a Eficácia da Ajuda, seguimos a orientação da Declaração adotada em Roma (fevereiro de 2003), no Fórum de Alto Nível sobre a Harmonização, bem como os princípios fundamentais propostos durante a Mesa Redonda de Marrakech (fevereiro de 2004) sobre a gestão centrada nos resultados em matéria de desenvolvimento [...], porque acreditamos que eles aumentarão os efeitos da ajuda na redução da pobreza e das desigualdades, incrementando o crescimento, o desenvolvimento das capacidades e a aceleração da realização dos ODM. (OCDE, 2005, p. 1)

Orientações que apareceram de forma difusa na Declaração de Roma são especificadas em Paris, a partir dos seguintes compromissos: 1. Apropriação: cabe aos países parceiros a liderança sobre as suas políticas e estratégias de desenvolvimento e a coordenação das ações em prol do desenvolvimento; 2 . Alinhamento: os países doadores devem apoiar as estratégias nacionais de desenvolvimento, assim como os procedimentos; 3. Harmonização: os doadores devem proceder de maneira harmonizada, transparente e coletivamente eficaz; 4. Gestão centrada em resultados: aprimorar a tomada de decisões e gerir os recursos centrada nos resultados; 5 . Responsabilidade mutual: os países parceiros - doadores e receptores da ajuda - são responsáveis pelos resultados obtidos no desenvolvimento. (OCDE, 2005, p. 3) Para cada um desses compromissos foram definidos indicadores quantitativos que permitissem averiguar os progressos até 2010.

Recomenda-se também: 1. Monitoramento: avalição periódica dos progressos na implementação dos compromissos acordados sobre a eficácia da ajuda; 2. Alinhamento: os países doadores devem se alinhar com as estratégias dos países parceiros; 3. Complementaridade: 
atentar para a excessiva fragmentação da ajuda em nível global, nacional ou setorial, o que diminui sua eficácia. Conclui que uma abordagem pragmática de divisão de trabalho e partilha de tarefas permite reforçar a complementaridade e pode reduzir os custos de transação. (OCDE, 2005, p. 6)

O Foro de Acra e o Foro de Busan, realizados em conjuntura marcada pela crise de 2008, mantêm as orientações de Roma e de Paris, mas ampliam o discurso para incorporar outros temas. Perpassa os documentos o reconhecimento de que os ODM não seriam alcançados até 2015 e eles passam a incorporar outros temas como coorrupção, clima e ampliação das parcerias com a sociedade civil, no sentido de responsabilidades compartilhadas, na agenda da cooperação para o desenvolvimento.

A Declaração de Acra é enfática em defender parcerias com organizações da sociedade civil: "Construir Parcerias de Desenvolvimento mais eficazes e inclusivas". Refere-se à necessidade de estabelecer compromissos com organizações da sociedade civil:

Aprofundaremos o nosso compromisso com as OSC, enquanto atores de desenvolvimento a título próprio, cujos esforços complementam os dos governos e do setor privado. Partilhamos um interesse em garantir que os contributos das OSC para o desenvolvimento atinjam o seu pleno potencial. Com este objetivo:

a) Convidamos as OSC a refletir sobre o modo como podem aplicar os princípios de Paris sobre eficácia da ajuda, de um ponto de vista das OSC.

b) Acolhemos com agrado as propostas das OSC para nos empenharmos conjuntamente num processo envolvendo múltiplos intervenientes, liderado pelas OSC, que promova a eficácia das OSC no desenvolvimento. Como parte desse processo, procuraremos: i) melhorar a coordenação dos esforços das OSC com programas governamentais, ii) incrementar a responsabilização com vista a resultados das OSC, e iii) meIhorar a informação sobre as atividades das OSC. 
c) Trabalharemos com as OSC de modo a criar um ambiente favorável, que potencie as suas contribuições para o desenvolvimento. (OCDE, 2008, art. 20, p. 6)

A Declaração de Busan está estruturada a partir dos seguintes eixos temáticos: 1. Negociando a mudança; 2 . Inclusão de novos atores com base em princípios compartilhados e compromissos diferenciados; 3. Melhorando a qualidade e a eficácia da cooperação para o desenvolvimento; 4. Cooperação transparente e responsável; 5. Promoção do desenvolvimento sustentável em situações de conflito e fragilidade; 6 . Alianças para fortalecer a resilência e reduzir as vulnerabilidades diante da adversidade; 7 . Da ajuda eficaz para um desenvolvimento eficaz; 8. Cooperação Sul-Sul e triangular com vistas ao desenvolvimento sustentável; 9. Setor privado e o desenvolvimento; 10. Financiamento relacionado comas mudanças climáticas; 11. Combatendo a corrupção e os fluxos ilícitos; 12. Financiamento relacionado com as mudanças climáticas; 13. O futuro: alianças para avançar.

Além da inclusão de novos temas, a Declaração de Busan salienta a busca de novas parcerias, referindo-se à OSC de uma maneira geral, mas destacando a inclusão do setor privado empresarial. Os Países de Renda Média (PRM) são também convocados para, em esforços compartilhados, reforçar sua atuação no âmbito da Cooperação Sul-Sul e cooperação técnica triangular. A seguinte passagem do documento é esclarecedora:

Um crescente número de atores - incluindo países de renda média, sócios da cooperação Sul-Sul e cooperação triangular e organizações da sociedade civil - têm se unido a outros atores, para forjar uma agenda mais includente de Paris e Acra, sob princípios comuns, porém respeitando a diversidade de seus compromissos (OCDE, 2010, p. 4)

\section{Conclusões}

Este texto buscou recuperar a trajetória da cooperação internacional para o desenvolvimento, visando, em primeiro lugar, a 
comprendê-la como parte de estratégias geopolíticas que objetivam minimizar conflitos entre nações desigualmente desenvolvidas e hierarquicamente posicionadas. Concebida no imediato pós-Segunda Guerra nos Estados Unidos, ela constrói um discurso entretecido por noções econômicas (desenvolvimento e subdesenvolvimento), políticas (liberdade, democracia, paz) e humanitárias, o que será assumido pelos governos de países integrantes da ordem mundial definida pelas disputas entre potências no contexto de desmonte do sistema colonial e da Guerra Fria. A extensão de seus programas de assitência técnica às áreas subdesenvolvidas passa a ser demandada pelos países e regiões menos desenvolvidas.

Incorporada à política externa dos países desenvolvidos, a cooperação internacional se concretiza por meio de organizações multilaterais, bilaterais e organizações não governamentais, constituindo uma complexa rede de interrelações. Ela foi comandada, até os anos 1970, principalmente, por entes governamentais que eventualmente se articulavam com organizações não estatais. A partir desse momento, são promovidas articulações cada vez mais orgânicas entre empresas, ONGD e governos. Em nome da eficiência e da eficácia na implementação de projetos, vão sendo abandonados o discurso e as práticas que visavam à conquista de direitos, para se privilegiarem ações puntuais e focalizadas em grupos de indivíduos e territórios específicos.

As conferências e foros promovidos por organizações interestatais internacionais, entre os anos 1990 e a primeira década deste século, redefinem a agenda de desenvolvimento e do seu sistema cooperativo internacional. De maneira mais ampla, as orientações se encaminham para a promoção de reformas no aparelho de Estado e nas organizações sociais não estatais, de forma a redefini-las não só internamente, como também nas suas interações. O objetivo é consolidar uma institucionalidade que não só complete o cumprimento da agenda definida pelos planos de reformas estruturais, como harmonize interesses e promova os princípios liberais como bases para a retomada do crescimento e do desenvolvimento. 
A configuração de ambientes caracterizados como de participação e interação entre empresas, organizações não governamentais e movimentos sociais, onde o Estado é apresentado como um parceiro a mais, é cultivada como forma de garantir a cooperação e firmar compromissos que, se não resultam de imediato, num novo modelo de desenvolvimento, devem contribuir para evitar a explicitação do temido conflito em momentos de crise do capital.

\section{Referências}

ARAGÃO, D. M. C. Desvio ao deserto neoliberal: a ONU, sua agenda de desenvolvimento e o caso da responsabilidade das corporações transnacionais. In: KRAYCHETE, E. S.; MILANI, C. R. S. (Org.). Desenvolvimento e cooperação internacional: relações de poder e política dos Estados. Salvador: Edufba, 2014. p. 77-93.

AYLLÓN PINO, B. A Cooperação triangular e as transformações da cooperação internacional para o desenvolvimento. Rio de Janeiro: Ipea, 2013. (Texto para discussão, n. 1845).

ATTAR, F. Dictionnaire des relations Internacionales de 1954 à nos jours. Paris: Éditions du Seuil, 2009.

AZEVEDO, C. Em nome da América: os corpos de paz no Brasil. São Paulo: Alameda, 2007.

BIEL, R. El nuevo imperialismo. México: Siglo Veintiuno, 2007.

BLOCK, F. L. Los orígenes del desorden económico internacional. México: Fondo de Cultura Económica, 1989.

COX, R. W. Los Informes Pearson y Jackson: una análisis deologico de las doctrinas de asistência al desarrollo. Revista Foro Internacional, México, v. 13, n. 5 (51), p. 4311-326, jan/mar. 1973.

ESCOBAR, A. La invención del Tercer Mundo: construcción y deconstrucción del desarrollo. Bogotá: Editorial Norma, 1998.

ESCUDEIRO, L. Cooperação Internacional como (Re)existência em Cuba. 2016. 205 p. Dissertação (Mestrado em Relações Internacionais) - Instituto de Humanidades, Artes e Ciências Professor Milton Santos, Universidade Federal da Bahia, Salvador, 2016.

HAYTER, T. Aid as imperialism. Londres: Penguin Books, 1971. 
IGLESIA-CARUNCHO, M. El impacto económico y social de la cooperación para el desarrollo. Madrid: La Catarata/IUDC-UCM, 2005.

KRAYCHETE, E. S. Desenvolvimento: razões e limites do discurso do Banco Mundial. Caderno CRH, Salvador, v. 19, n. 48, p. 415-430, set./dez. 2006.

KRAYCHETE, E. S. O lugar das organizações não governamentais no entrecruzamento entre as noções de desenvolvimento e cooperação internacional. Caderno CRH, Salvador, v. 25, n. 65, p. 251-267, maio/ago. 2012.

LANCASTER, C. Foreign aid: diplomacy, development, domestic politics. Chicago: The University of Chicago Press, 2007.

MÉSZAROS, I. O poder da ideologia. São Paulo: Editorial Boitempo, 2004.

MILANI, C. R. S. Organizações multilaterais de desenvolvimento. In. SOUZA, A. de M. Repensando a cooperação internacional para o desenvolvimento. Brasília: Ipea, 2014.

MORAES, R. C. de. Estado, desenvolvimento e globalização. São Paulo: Ed. Unesp, 2006.

OCDE. Organización para la Cooperación y el Desarrollo Económicos. Comité de Ayuda al Desarrollo. Fundaciones filantrópicas y cooperación al desarrollo. Paris, 2004.

OCDE. Organisation for Economic Co-Operation and Development. Declaração de Paris sobre a eficácia da ajuda ao desenvolvimento: apropriação, harmonização, alinhamento, resultados e responsabilidade mútua. Paris, 2005. Disponível em: <www.oecd.org/ dataoecd/56/41/38604403>.

OCDE. Organisation for Economic Co-operation and Development. Busan partnership for effective development cooperation fourth high level. In: FORUM ON AID EFFECTIVENESS, 2011, Busan, Republic of Korea, 2011a. Disponível em: <www.oecd.org/dac/evaluationnetwork/pde>. Acesso em: 1 abr. 2016.

OCDE. Organisation for Economic Co-operation and Development. Thematic Session on Public-Private Co-operation for Broad-based, Inclusive, and Sustainable Growth, Fourth High-Level. FORUM ON AID EFFECTIVENESS. Busan, Republic of Korea- BEXCO, 2011b. Disponivel em: <http://www. aideffectiveness.org/busanhlf4/images/stories/oecd/49482111.pdf>. Acesso em: 3 abr. 2016.

OCDE. Organización para la Cooperación y el Desarrollo Económicos. Informe Final sobre la Evaluación de la Aplicación de la Declaración de París, 
Fase 2, Copenhague, Mayo 2011c. Disponível em: <www.oecd.org/dac/ evaluationnetwork/pde>. Acesso em: 3 abr. 2016.

OCDE. Organización para la Cooperación y el Desarrollo Económicos. Agenda para a Acção de Accra, 2008. In: FÓRUM DE ALTO NÍVEL SOBRE A EFICÁCIA DA AJUDA, 2008, Accra, Gana. Disponível em: <http://www.oecd. org/dataoecd/58/59/41202060>.

OCDE. Organización para la Cooperación y el Desarrollo Económicos.

Declaração Foro de Roma. Disponível em: <www.ocde.org>. Acesso em: 4 jun. 2016.

PEARSON, L. B. El desarrollo empresa común: una nueva estrategia global. El Correo, Paris, Ano XXIII, p. 4-9, Feb. 1970.

PNUD. Programa das Nações Unidas para o Desenvolvimento. Study of the capacity of the United Nation Development System, 1969. Disponível em: <www.pnud.org>. Acesso em: 15 abr. 2016.

PNUD. Programa das Nações Unidas para o Desenvolvimento. 1992. Disponível em: <www.pnud.org>. Acesso em: 15 jun. 2016.

PNUD. Programa das Nações Unidas para o Desenvolvimento. 2004. Disponível em: <www.pnud.org>. Acesso em: 15 jun. 2016.

PNUD. Programa das Nações Unidas para o Desenvolvimento. Comisión sobre el sector privado y el desarrollo. El impulso del empresariado: el potencial de las empresas al servicio de los pobres. Nueva York: ONU, 2004.

RIST, G. El desarrollo: historia de una creencia occidental. Madrid: Livros Cararata, 2002.

SAUNDERS, F. S. Quem pagou a conta? A guerra secreta da CIA contra a Cultura. Rio de Janeiro: Record, 2008.

VIANNA, S. B. Duas tentativas de estabilização: 1951-1954. In: ABREU, M. de P. (Org.). A ordem do progresso: cem anos de política econômica, 1889-1999. Rio de Janeiro: Campus, 1992.

WORLD BANK. The World Bank Annual Report. Wadhington D.C., 1990.

WORLD BANK. The World Bank Annual Report. Wadhington D.C., 1991.

WORLD BANK. Aid Architecture: an overview of the mais trends in official development assistence flows. Wadhington D.C., 2008. 


\section{Notas explicativas}

1 Este capítulo traz resultados da pesquisa desenvolvida no âmbito do projeto $A$ Reinvenção do desenvolvimento: agências multilaterais e produçãoo sociológica contemporânea (Projeto Universal do CNPq - Edital n. 14, 2012), coordenada pela doutora Anete Brito Leal Ivo.

2 "[...] multilateralismo por un lado y una tolerancia de factode ciertas relaciones neocoloniales bilaterales por otro."

3 " [...] propuso un gran programa de ayuda norteamericana para el financiamento de la continuación de un alto nivel de las exportaciones de los Estados Unidos."

4 Países participantes da Conferência de Bandung: Ásia (Afeganistão, Birmânia, Camboja, Ceilão, República Popular da China, Filipinas, Índia, Indonésia, Japão, Laos, Nepal, Paquistão, República Democrática do Vietnã, Vietnã do Sul, e Tailândia); Oriente Médio (Arábia Saudita, lêmen, Irã, Iraque, Jordânia, Líbano, Síria, e Turquia); África (Costa do Ouro, atual Gana, Etiópia, Egito, Líbia, Libéria e Sudão).

5 "[...] afirmaba que los Estados Unidos intervendrían del lado de la libertad dondequiera que fuese necessário."

6 Paul Gray Hoffman foi, em seguida, diretor gerente do Fundo Especial das Nações Unidas (1959/1956) e primeiro administrador do Programa das Nações Unidas para o Desenvolvimento (PNUD) (1966-1972). Foi também diretor da Ford Fundation.

7 Después de los primeros años del Plan Marshall, los líderes de la mayoría de los países de Europa Occidental estaban dispuestos a adaptarse a la meta norteamericana de una economia mundial multilateral, a condición de que no fuesen demasiado elevado los costos internos de esta adaptación.

8 É fruto das negociações, no âmbito desse programa, a criação da Comissão Mista Brasil-Estados Unidos, composta de representantes americanos e brasileiros (1951-1953), voltada para detectar os gargalos que travavam o desenvolvimento do país. Os resultados dos estudos projetaram uma demanda de US\$ 387 milhões para investimentos, especialmente em infraestrutura. Do total demandado, o Eximbank financiou apenas US\$ 186 milhões, dentre os quais US\$ 60 milhões foram destinados à empresa canadense Traction Light \& Power Campany Ltda. (VIANNA, 1992, p. 133)

9 Este item está baseado nos artigos "Desenvolvimento: razões e limites do discurso do Banco Mundial" e "O lugar das organizações não governamentais no entrecruzamento entre as noções de desenvolvimento e cooperação internacional"., ambos de autora deste capítulo. (KRAYCHETE, 2006, 2012)

10 O CAD é composto pelos seguintes países: Alemanha, Austrália, Áustria, Bélgica, Canadá, Coreia do Sul, Dinamarca, Espanha, Eslovênia, Eslováquia, Estados Unidos, Finlândia, França, Grécia, Países Baixos, Irlanda, Itália, Japão, Luxemburgo, Noruega, Nova Zelândia, Polônia, Portugal, Suécia, Suíça, Reino Unido e a Comissão Europeia. São observadores permanentes o Fundo Monetário Internacional (FMI), o Banco Mundial (BM) e o Programa das Nações Unidas para o Desenvolvimento (PNUD).

11 Em 1962, foi criado o Ministério para Cooperação Internacional. Em 1983, ao seu nome foi acrescentada a palavra Desenvolvimento.

12 Hoje, Agência de Cooperação Internacional do Japão (JICA, da sigla em inglês) 
13 Excede os objetivos deste texto a análise da cooperação internacional dos países socialistas. Vale registrar, no entanto, que, sob a liderança da URSS, foi criado, em 1949, o Conselho de Ajuda Mútua Econômica (CAME), com a finalidade de promover e coordenar a cooperação entre os países integrantes do bloco socialista e outros com menor desenvolvimento econômico e social. Além da URSS, no momento da fundação, eram membros a República Democrática da Alemanha, Romênia, Bulgária, Checoslováquia, Hungria e Polônia. Além desses países fundadores, foram se integrando: Albânia (mas se retira em 1968), Mongólia (1962), Cuba (participava como observador e se integra em 1972) e Vietnã (1977). (ESCUDEIRO, 2016, p. 114)

14 [...] deve dirigirse a la creación de las condiciones propicias para la expansión de la economía global. La ayuda oficial complementaría a inversión privada [...]. La ayuda operaria también como un inventivo para que los gobiernos de los países pobres adoptasen políticas compatibles con una estrategia de crecimiento a través de la inversión estranjera, un incentivo que se haría efectivo mediante una vigilância multilateral administrada y controlada por el Banco Mundial y el FMI. 